ISSN 1810-3030 (Print) 2408-8684 (Online)

Journal of Bangladesh Agricultural University

Journal home page: http://baures.bau.edu.bd/jbau, www.banglajol.info/index.php/JBAU

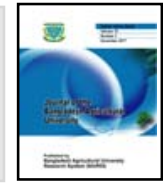

\title{
Present status and problem confrontation of oilseed cultivation in southwest region of Bangladesh
}

\author{
Suraya Pervin, Antu Roy Chowdhury, Md. Matiul Islam, Mohammad Bashir Ahmed and \\ Rubayet Ara ${ }^{1}$
}

Agrotechnology Discipline, Khulna University, Khulna-9208

${ }^{1}$ Upazila Agriculture Officer, Batiaghata, Khulna

\begin{tabular}{|c|c|}
\hline ARTICLE INFO & Abs \\
\hline $\begin{array}{l}\text { Received: } 22 \text { March } 2018 \\
\text { Accepted: } 06 \text { June } 2018\end{array}$ & \multirow{3}{*}{$\begin{array}{l}\text { The present piece of research was conducted to explore the present status and problem confrontation of } \\
\text { oilseed cultivation. Besides, relationship of the selected characteristics of the respondents with their } \\
\text { problem confrontation was explored. This study was conducted at three selected villages namely Fultola, } \\
\text { Debitola and Hetalbunia of Batiaghata upazila. Data were collected from purposive randomly selected } 82 \\
\text { respondents during the period of } 07 \text { to } 27 \text { May, } 2017 \text {. Appropriate scales were used to measure the } \\
\text { variables of the study. Correlation test was used to ascertain the relationship between the personal } \\
\text { characteristics with the faced problems. Average age of the respondents was } 50.43 \text { years. Around two- } \\
\text { third ( } 63.4 \text { percent) of the respondents belonged to nuclear family with small to medium ( } 65.9 \text { percent) } \\
\text { family size with an average of } 5.87 \text { years of schooling. Most ( } 98.7 \text { percent) of the respondents had scanty } \\
\text { land ownership. All of them had oilseed cultivation experience and } 57.3 \text { percent had organizational } \\
\text { participation. Their average annual income was } 1,06,122 \text { Tk. Three-fourth ( } 75.6 \text { percent) of the } \\
\text { respondents had medium extension contact and about two-third ( } 69.5 \text { percent) had low cosmopoliteness. } \\
\text { Among the respondents } 68.3 \text { percent had high knowledge, } 81.7 \text { percent had favorable attitude, and among } \\
\text { oilseed sesame ranked first position in case of cultivation practice. Water logging, salinity and lack of } \\
\text { improved technology for planting and harvesting ranked } 1^{\text {st }}, 2^{\text {nd }} \text { and } 3^{\text {rd }} \text { position, respectively, among the } \\
\text { problems. Annual income and attitude had negative significant relationship with problem confrontation. } \\
\text { Respondents had favorable attitude towards oilseed cultivation. This attitude may be a tool for the oilseed } \\
\text { farmers to increase the oilseed cultivation status in the study area. }\end{array}$} \\
\hline $\begin{array}{l}\text { Keywords: } \\
\text { Present status, Problem } \\
\text { confrontation, Oilseed cultivation }\end{array}$ & \\
\hline & \\
\hline
\end{tabular}

\section{Introduction}

Oilseed crops are those plants that can provide oil from seeds. The edible oil producing plants constitute a major proportion of agricultural crop in Bangladesh. Next to the food grain oilseed crops and vegetables are categorized as two major groups depending on their area coverage and production. Oilseed is the most important source of vegetable oil. It plays a vital role in agricultural sector of Bangladesh. However, it is a matter of sorrow that, the production of oilseed cannot meet up country's annual demand. A lot of foreign exchange is spent every year for importing edible oils and oilseeds to fulfill the domestic requirement (Hossain, 2017). Up-to-date and nationally representative data and information were scarce in this regard.

Edible oils play a very important role in human nutrition (Yanai et al., 2015). Oils were not only important for human diets but also serves as important raw material for industrial use such as in making soaps, paints, varnishes, hair oils, lubricants, textile auxiliaries, pharmaceuticals, etc. Oilcakes and meals are used as animal feeds and manures (Rizvi et al., 2012).

At present, oilseed crops are grown in 3,38,000 hectares which is $2.47 \%$ of the cultivable land producing $3,73,000$ tons of oilseeds. The domestic production of edible oil can only meet about $20 \%$ of the country's annual demand and rest $80 \%$ is imported which costs more than Tk. twenty billion. It was found that in the imported oils and oilseeds, soybean ranks first $(4,34,000$ $\mathrm{t}=50 \%)$ followed by palm oil $(3,41,000 \mathrm{t}=39 \%)$, and the rests are mustard and sunflower oil $(97,000 \mathrm{t}=11 \%)$ (BARI, 2008).

The area and production of oilseeds are gradually declining due to mainly (i) low yield potential of the traditional oilseed crop varieties; (ii) high infestation of diseases and pests, (iii) instability of yield due to microclimatic fluctuation, and (iv) expansion of irrigation facilities and more profitable crops are available instead of oilseeds in the cropping patterns. In Bangladesh major oilseeds are mustard, sesame, linseed, peanut, sunflower, soybean and coconut. Minor oilseeds are niger seed, castor, safflower, lemon grass, etc. We use soybean oil in purpose of food preparation to a greater extent. Sunflower is also very good quality oil, which has less amount of cholesterol. Peanut oil is rich in vitamin E content (McKevith, 2005).

Majority of the oil crops (mustard, sesame, soybean, sunflower, etc.) are grown in the Rabi (winter) season. Peanut is grown in both Rabi and Kharif season. Among the total land used under oilseed cultivation, $60 \%$ is used for mustard cultivation (http://en.banglapedia.org, 
November 30, 2017). Sesame is cultivated in a good amount of land in Khulna region. Coconut also grows well in Khulna region. But the other oilseeds like sunflower, soybean, peanut, etc. are not cultivated here or cultivated on a very small amount of land, though they are also very important oilseeds.

Considering the abovementioned facts this study was conducted to investigate the present status of oilseed cultivation in southwest region of Bangladesh in the context of area, production, yields and other related aspects, along with pointing out the problems confronted by the farmers. The specific objectives of the study were:

i. to describe the selected characteristics of the oilseed growers

ii. to explore the present oilseed cultivation status

iii. to analyze the knowledge, attitude and practice of the farmers regarding oilseed cultivation

iv. to identify the problems being faced by the farmers in oilseed cultivation, and

v. to find out the relationship between selected characteristics of the respondents with faced problems

\section{Methodology}

Locale and sample: Batiaghata upazila is located close to Khulna city and one of the largest upazila in respect of area of Khulna district. This area is easily accessible by road and oilseeds are widely grown crop of the area, and above all, well known to the researchers as they were the faculties and students of adjacent Khulna University. That is why, the area was selected as the locale of the study. Batiaghata upazila has 7 unions (divided in to 21 blocks comprising 168 villages). On the basis of access convenience, 3 villages (Fultola, Debitola and Hetalbunia) of 2 blocks (Fultola and Baherdanga) were purposively selected and 82 oilseed growers of those 3 villages were randomly selected and interviewed as the sample of the study. Thus the sample selection method was purposive random sampling technique (Tongco, 2007).

Measurement of variables: Present status and problem confrontation of oilseed cultivation were main focus to be assessed in this study. At the same time the following characteristics of the farmers were selected to explore relationships with one of the main focuses (problem confrontation): age, educational qualification, family type, family size, farm size, experience in oilseed cultivation, organizational participation, annual family income, extension contact, cosmopoliteness, training, knowledge on oilseed cultivation, attitude towards oilseed cultivation and practice regarding oilseed cultivation. Standard procedures were followed for measuring the variables.

The respondents were asked whether they had received any training on agriculture or not for measuring training status. If the response was positive, they had been further asked whether the training was on oilseed production or not. By this way the number of training received by the respondents was differentiated and calculated (Table 1 and Fig. 6).

Five questions were asked to each respondent to determine knowledge on oilseed cultivation. The questions covered different aspects of oilseed cultivation. Each question was assigned by ' 2 ' marks. If an oilseed farmer answered all of those questions correctly, obtained ' 10 ' marks. If any farmer failed to answer any of the question correctly, obtained ' 0 ' marks. So the range varied between 0 to 10 ; where, 0 means no knowledge, and 10 means highest knowledge (Table 2).

Attitude refers to the individual farmer's outlook and positive or negative reaction and emotional feelings towards oilseed cultivation. A five point Likert scale was used to determine the attitude of the farmers where 'strongly agree', 'agree', 'undecided', 'disagree' and 'strongly disagree' were assigned 5, 4, 3, 2 and 1 scores, respectively, for the positive statements. Whereas, for the negative statements- 'strongly agree', 'agree', 'undecided', 'disagree' and 'strongly disagree' were assigned 1, 2, 3, 4 and 5 scores, respectively (Likert, 1932). There were five positive and five negative statements for calculating the total scores of attitude towards oilseed cultivation. So the scores ranged from 10 to 50; where, 10 means least favorable attitude and 50 means highest positive attitude (Table 3 ).

Practice was assessed and described by obtaining firsthand information from the respondents on (a) last five years cropping pattern (Table 4), (b) cultivated major oilseed crops (Table 5), and (c) purpose of oilseed cultivation (Table 6). There were lots of practice issues regarding oilseed cultivation; however, for data handling convenience only the mentioned three aspects had been included.

Problem confrontation by the respondents in oilseed cultivation: A scale was used for measuring the problem (Bashar, 2006). The interview schedule contained fifteen possible statements regarding the faced problems. Each respondent indicated the extent of hindrance caused to him by each of the problem through five responses (mentioned below). Problem Confrontation Index (PCI) was calculated by using following formula:

$\begin{aligned} \text { PCI }= & \left(\mathrm{N}_{1} \times 0\right)+\left(\mathrm{N}_{2} \times 1\right)+\left(\mathrm{N}_{3} \times 2\right)+\left(\mathrm{N}_{4} \times 3\right)+ \\ \text { PCI }= & \text { Problem Confrontation Index } \\ \mathrm{N}_{1}= & \text { No problem } \\ \mathrm{N}_{2}= & \text { Less severe } \\ \mathrm{N}_{3}= & \text { Medium severe } \\ \mathrm{N}_{4}= & \text { Severe } \\ \mathrm{N}_{5}= & \text { Highly severe }\end{aligned}$


Preparation and pre-testing of interview schedule: An interview schedule was prepared for collecting data and tested before collecting data.

Data collection, processing and analysis: Data were collected after preparing the final interview schedule using face to face interviews by the researchers themselves during May 07 to 27, 2017. After that data were edited and transferred to coding sheet with numerical scores given to each question. Data analysis was done by using computer with SPSS and MS Excel. The present status of oilseed cultivation was collected by interviewing the Upazila Agriculture Officer (UAO) of Batiaghata upazila. The researchers interviewed the UAO on a prescheduled day at the office compound where the incumbent UAO furnished the required data from different office records and notes. Pearson Product Moment correlation coefficient was used to determine the strength of association between the respondents selected characteristics and their problem confrontation in oilseed cultivation.

\section{Results and Discussion}

\section{Selected characteristics of the respondents:}

Age: About half (48.8 percent) of the respondents fall in the middle aged category compared to 31 percent in old aged category. The minimum age of the respondents was 29 years though the youth attain the ability of hard-work at around 18 years of age (Table 1). They have the opportunity to engage themselves in farming occupation earlier, but due to social outlook and personal thinking the youth of our country wants to join in other nonagricultural job sector, and thinks that job as prestigious one.

Educational qualification: About half (47.6 percent) of the respondents had primary to secondary level of education. Among the respondents 29.3 percent belonged to the higher secondary education category compared to 24.4 percent, 23.2 percent, 11 percent and 4.9 percent belonged to secondary, primary, undergraduate and post-graduate category of education, respectively (Table 1). The maximum educational qualification of the respondents was 16 years of schooling. According to the intimate discussion with the highly educated respondents and local elites, the researchers came to learn that the graduate respondents joined the farming operation as some of them didn't get any prestigious job, some of them had much land in the field, and some of them wanted to do easier job and wanted to earn more profit employing less effort, so joined this occupation.

Family type: About two third (63.4 percent) of the farmers had nuclear type of family while 31.7 percent and 4.9 percent had joint and extended family, respectively (Table 1). It was also revealed during discussion with respondents that the rural people were somewhat conscious about family planning and felt comfortable to belong to a nuclear family.
Family size: Family size of the respondents ranged from 3-11, with a mean of 5.65 and standard deviation 1.94 (Table 1). Among the respondents 65.9 percent had small to medium sized family. However, 34.1 percent had large sized family. The maximum number of family members was 11 . So, it might be said that in rural community there exists large families though now a days the large families are breaking down into smaller and also the land is being fragmented due to succession and as a result the cultivable land is decreasing.

Farm size: The average farm size was 0.38 hectares and the standard deviation was 0.27 . About two-third (64.6 percent) of the farmers possessed small sized farm compared to 31.7 percent and 1.2 percent of them having marginal and medium sized farm, respectively. Among the respondents 2.4 percent were landless. The observed farm size scores of the farmers varied from 0 to 1.06 hectares (Table 1). None of them had large sized ( $3 \mathrm{ha}$ ) farm (Fig. 1).

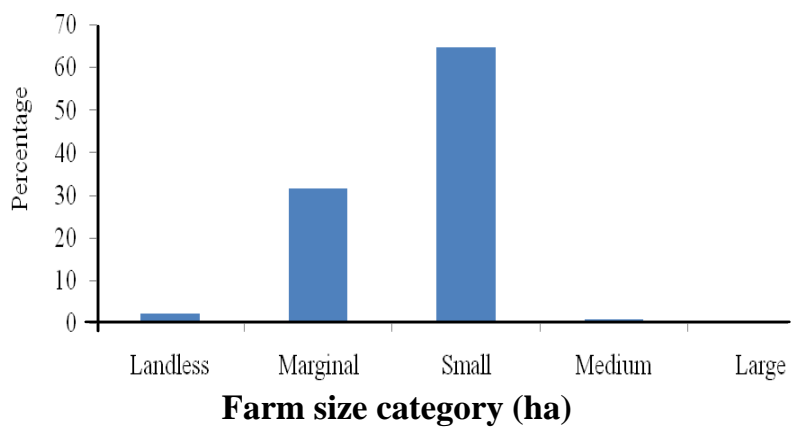

Fig. 1. Distribution of respondents according to their farm size

Experience in oilseed cultivation: All of the respondents had experience in oilseed cultivation (Table 1).

Organizational participation: Involvement of a respondent with different organizations was treated as organizational participation. About half (57.3 percent) of the respondent farmers had more or less organizational participation and 42.7 percent farmers didn't have any organizational participation. Table 1 indicates that most (97.87 percent) of the farmers had low organizational participation. No farmers had high organizational participation (Table 1). Those respondents who didn't have much agricultural land and were not full-time farmer normally didn't have any organizational participation. Akanda et al. (2017) reported that organizational participation of the farmers was one of the vital predictors towards motivation on sunflower cultivation.

Annual family income: Family income of the respondents ranged from $50,000 \mathrm{Tk}$. to $1,80,000 \mathrm{Tk}$. with a mean of $1,06,122 \mathrm{Tk}$. Data (Table 1) reveal that about half of the respondents (54.9 percent) had low income while 23.2 percent had medium and 22 percent had high income (Table 1). The economical condition of the farmers was not satisfactory. They were living under the poverty line. They had 1,06,122 Tk. annual family 
income in average, whereas the annual national average nayadiganta. com, November 15, 2017).

income was $\$ 1610 \sim$ i.e., 1,33,581.7 Tk. (www.daily

Table 1. Distribution of the respondents based on their personal characteristics

\begin{tabular}{|c|c|c|c|c|c|c|c|c|}
\hline \multirow{2}{*}{$\begin{array}{l}\text { Parameter } \\
\text { / Variable }\end{array}$} & \multirow[t]{2}{*}{ Category } & \multirow[t]{2}{*}{ Score } & \multicolumn{2}{|c|}{$\begin{array}{c}\text { Respondents } \\
(\mathrm{N}=82)\end{array}$} & \multirow[t]{2}{*}{ Mean } & \multirow[t]{2}{*}{ SD } & \multirow[t]{2}{*}{ Min. } & \multirow[t]{2}{*}{ Max. } \\
\hline & & & Number & Percentage & & & & \\
\hline \multirow{4}{*}{$\begin{array}{c}\text { Age } \\
\text { (Years) }\end{array}$} & Young & $\leq 35$ & 11 & 13.4 & \multirow{4}{*}{50.43} & \multirow{4}{*}{12.67} & \multirow{4}{*}{29} & \multirow{4}{*}{75} \\
\hline & Middle & $36-55$ & 40 & 48.8 & & & & \\
\hline & Old & $>55$ & 31 & 37.8 & & & & \\
\hline & No & 0 & 6 & 7.3 & & & & \\
\hline \multirow{5}{*}{$\begin{array}{l}\text { Education } \\
\text { (Schooling } \\
\text { years) }\end{array}$} & Primary & $1-5$ & 19 & 23.2 & \multirow{5}{*}{5.87} & \multirow{5}{*}{4.88} & \multirow{5}{*}{0} & \multirow{5}{*}{16} \\
\hline & Secondary & $6-10$ & 20 & 24.4 & & & & \\
\hline & HSC & $11-12$ & 24 & 29.3 & & & & \\
\hline & Honors & $13-16$ & 9 & 11 & & & & \\
\hline & Above & $>16$ & 4 & 4.9 & & & & \\
\hline \multirow{3}{*}{$\begin{array}{c}\text { Family type } \\
\text { (Category) }\end{array}$} & Nuclear & - & 52 & 63.4 & \multirow{3}{*}{-} & \multirow{3}{*}{-} & \multirow{3}{*}{-} & \multirow{3}{*}{-} \\
\hline & Joint & - & 26 & 31.7 & & & & \\
\hline & Extended & - & 4 & 4.9 & & & & \\
\hline \multirow{4}{*}{$\begin{array}{l}\text { Family Size } \\
\text { ( No. of } \\
\text { members) }\end{array}$} & Small & $\leq 4$ & 29 & 35.4 & \multirow{4}{*}{5.65} & \multirow{4}{*}{1.94} & \multirow{4}{*}{3} & \multirow{4}{*}{11} \\
\hline & Medium & $\overline{5-6}$ & 25 & 30.5 & & & & \\
\hline & Large & $>6$ & 28 & 34.1 & & & & \\
\hline & Landless & $<0.02$ & 2 & 2.4 & & & & \\
\hline \multirow{4}{*}{$\begin{array}{l}\text { Farm size } \\
\text { (ha) }\end{array}$} & Marginal & $0.02-0.2$ & 26 & 31.7 & \multirow{4}{*}{0.38} & \multirow{4}{*}{0.27} & \multirow{4}{*}{0} & \multirow{4}{*}{1.06} \\
\hline & Small & $0.2-1$ & 53 & 64.6 & & & & \\
\hline & Medium & $1-3$ & 1 & 1.2 & & & & \\
\hline & Large & $>3$ & 0 & 0 & & & & \\
\hline
\end{tabular}

Table 1. Continued...

\begin{tabular}{|c|c|c|c|c|c|c|c|c|}
\hline \multirow{2}{*}{$\begin{array}{l}\text { Parameter } \\
\text { / Variable }\end{array}$} & \multirow[t]{2}{*}{ Category } & \multirow[t]{2}{*}{ Score } & \multicolumn{2}{|c|}{$\begin{array}{c}\text { Respondents } \\
(\mathrm{N}=82)\end{array}$} & \multirow[t]{2}{*}{ Mean } & \multirow[t]{2}{*}{ SD } & \multirow[t]{2}{*}{ Min. } & \multirow[t]{2}{*}{ Max. } \\
\hline & & & Number & Percentage & & & & \\
\hline \multirow[t]{2}{*}{ Experience } & Yes & - & 82 & 100 & \multirow[t]{2}{*}{-} & \multirow[b]{2}{*}{ - } & \multirow[t]{2}{*}{-} & \multirow{2}{*}{-} \\
\hline & No & - & 0 & 0 & & & & \\
\hline Organizational & Yes & - & 47 & 57.3 & \multirow[b]{2}{*}{ - } & \multirow[b]{2}{*}{-} & & \multirow[b]{2}{*}{ - } \\
\hline Participation & No & - & 35 & 42.7 & & & & \\
\hline Organizational & Low & $1-7$ & 46 & 97.87 & \multirow{3}{*}{0.89} & \multirow{3}{*}{1.04} & & \\
\hline Participation & Medium & $8-14$ & 1 & 2.12 & & & \multirow[t]{3}{*}{0} & \multirow[t]{3}{*}{9} \\
\hline \multirow{2}{*}{ (Category) } & High & $>14$ & 0 & 0 & & & & \\
\hline & Low & $0-1,00,000$ & 45 & 54.9 & $1,06,122$ & & & \\
\hline \multirow[t]{2}{*}{$\begin{array}{l}\text { Income } \\
\text { (Tk.) }\end{array}$} & Medium & $\begin{array}{l}1,00,001- \\
1,30,000\end{array}$ & 19 & 23.2 & \multirow{2}{*}{$\begin{array}{l}\text { (Annual national } \\
\text { average } \\
=1610 \$ \text { ) }\end{array}$} & \multirow[t]{2}{*}{$\begin{array}{c}32,048 . \\
34\end{array}$} & \multirow[t]{2}{*}{50,000} & \multirow[t]{2}{*}{$1,80,000$} \\
\hline & High & $>1,30,000$ & 18 & 22 & & & & \\
\hline \multirow{5}{*}{$\begin{array}{l}\text { Extension } \\
\text { Contact } \\
\text { (Category) }\end{array}$} & No & 0 & 0 & 0 & \multirow{5}{*}{14.561} & \multirow{5}{*}{3.76} & \multirow{5}{*}{4} & \multirow{5}{*}{21} \\
\hline & Low & $1-9$ & 6 & 7.3 & & & & \\
\hline & Medium & $10-18$ & 62 & 75.6 & & & & \\
\hline & High & $>18$ & 14 & 17.1 & & & & \\
\hline & No & 0 & 2 & 2.4 & & & & \\
\hline \multirow{3}{*}{$\begin{array}{c}\text { Cosmopoliteness } \\
\text { (Category) }\end{array}$} & Low & $1-5$ & 57 & 69.5 & & & & \\
\hline & Medium & $6-10$ & 20 & 24.4 & 4.39 & 1.92 & 0 & 11 \\
\hline & High & $>10$ & 3 & 3.7 & & & & \\
\hline Agricultural & Yes & - & 69 & 84.1 & & & & \\
\hline training & No & - & 13 & 15.9 & - & - & - & - \\
\hline Oilsed training & Yes & - & 67 & 81.7 & & & & \\
\hline Uisseed training & No & - & 2 & 2.4 & - & - & - & - \\
\hline
\end{tabular}

Extension contact: Extension contact means the level of communication to different persons as DAE officers, NGO officers, input dealers, neighbors/relatives, and so on. The observed extension contact scores of the farmers ranged from 4 to 21 with a mean of 14.56. Among the farmers 75.6 percent had medium extension contact as compared to high (17.1 percent) and low (7.3 percent) contact. None of the respondents belonged to "no" extension contact category (Table 1). Most of the farmers had extension contact. But that was not full satisfactory. The upazila level extension agents normally visit the farmers having some land ownership and performing intensive agriculture. Thus, the landless farmers, sometimes, didn't get proper attention and as a result didn't have appropriate and adequate information about oilseeds. They cultivated mainly sesame as they know about it previously. They didn't cultivate other oilseeds, because they were lacking information and 
didn't know about the benefits of other oilseed crops. Akanda et al. (2017) found that training and contact with various sources of information were among the vital predictors towards motivation on oilseed (e.g., sunflower) cultivation.

Cosmopoliteness: Cosmopoliteness referred to the respondent's orientation/visitation to outside of his own social system. Cosmopoliteness of the respondents ranged from $0-11$ with a mean of 4.39 and standard deviation of 1.92. Data reveal that about two-third of the respondents (69.5 percent) had low cosmopoliteness compared to 24.4 percent having medium and 3.7 percent high cosmopoliteness. The respondents didn't go to district headquarter. Some of them went to upazila headquarter sometimes and very negligible amount of respondents rarely went to capital city. Around 2.4 percent of the farmers had no cosmopoliteness (Table 1).

Training: The observed training exposure of the farmers was not so much satisfactory. Among the respondents 84.1 percent received training and 15.9 percent didn't get any agricultural training (Table 1). The findings show that most of the farmers (97.1 percent), who received agricultural training, also received oilseed cultivation training, as oilseed was a major crop of the study area. But, most of the oilseed trainings were mainly based on sesame cultivation. Training on other oilseeds like mustard, soybean, etc. was not conducted there. So, the farmers didn't know about the benefits and cultivation process of those oilseeds, and they didn't become encouraged to cultivate other oilseeds. There was little training on sunflower cultivation. But the number of those trainings was too low and was conducted by BRAC or other NGOs. Sunflower was a prospective oilseed crop in that locality. But, there was no GO organized training on sunflower in that area.

\section{Present status of oilseed cultivation at Batiaghata upazila:}

Information on different aspects regarding the status of oilseed cultivation was collected from the Upazila Agriculture Office of Batiaghata upazila. The total cultivable land of Batiaghata upazila was 19,127 ha, and cropping intensity was $178 \%$. Among the total cultivable land rice, wheat, jute, horticultural crops, oilseed crop and other crops occupy 17,515 ha, 2 ha, 18 ha, 660 ha, 1,800 ha and 365 ha area, respectively (Fig. 2).

Total area under oilseed cultivation was $1,800 \mathrm{ha}$, and production was 1,620 ton (approx.) for sesame (Fig. 3). For mustard, sunflower and coconut 11 ha, 5 ha and 140 ha land was used respectively. Production of mustard, sunflower and coconut was 9.77 ton, 11.25 ton and 910 ton respectively (Fig. 4). Average standard yield of mustard and sunflower were $0.89 \mathrm{tha}^{-1}$ and $2.25 \mathrm{t} \mathrm{ha}^{-1}$, respectively, in the study area. Sesame occupies maximum area under oilseed cultivation. The cultivation of mustard and sunflower was very much low though the yield potential was good. Farmers didn't cultivate sunflower due to some post-harvest and marketing problems. Coconut was cultivated in homestead area and the yield was good as this area was suitable for coconut cultivation (Fig. 4).

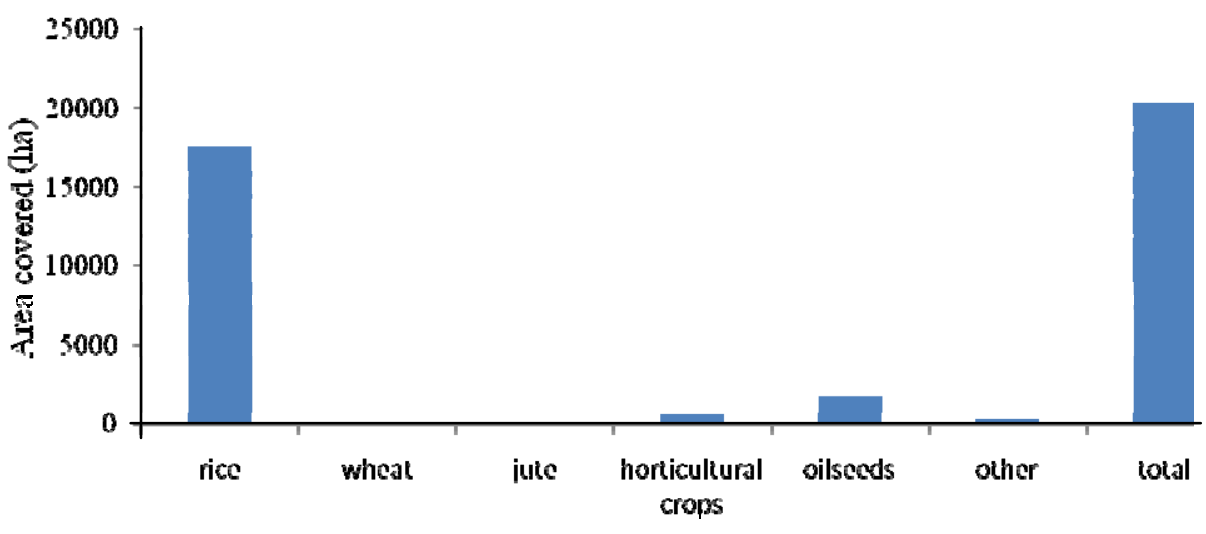

Crop names

Fig. 2. The arable land use pattern

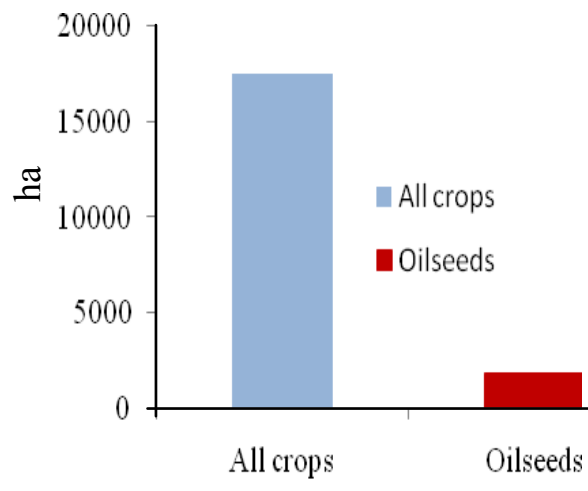

Area (ha)

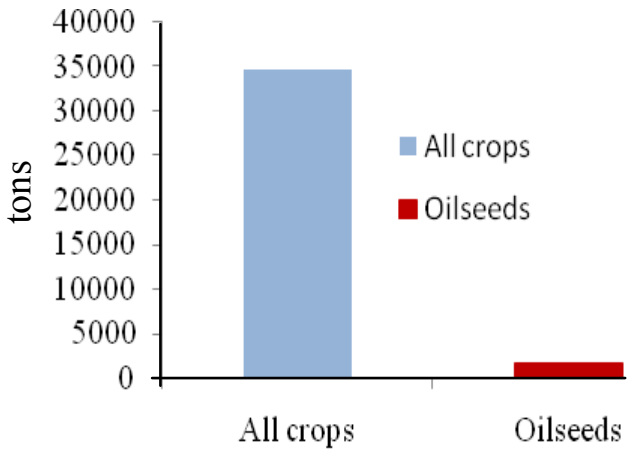

Production (tons) 
Fig. 3. Area under oilseed cultivation against total cultivated land

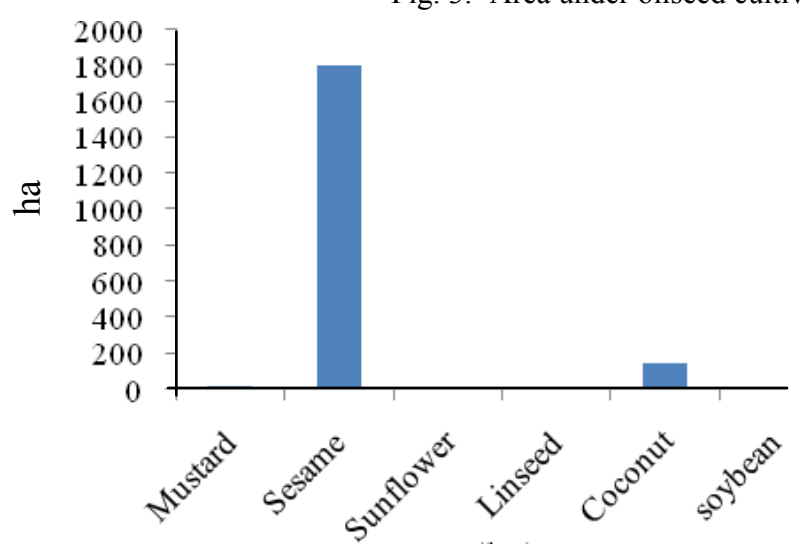

Area (ha)

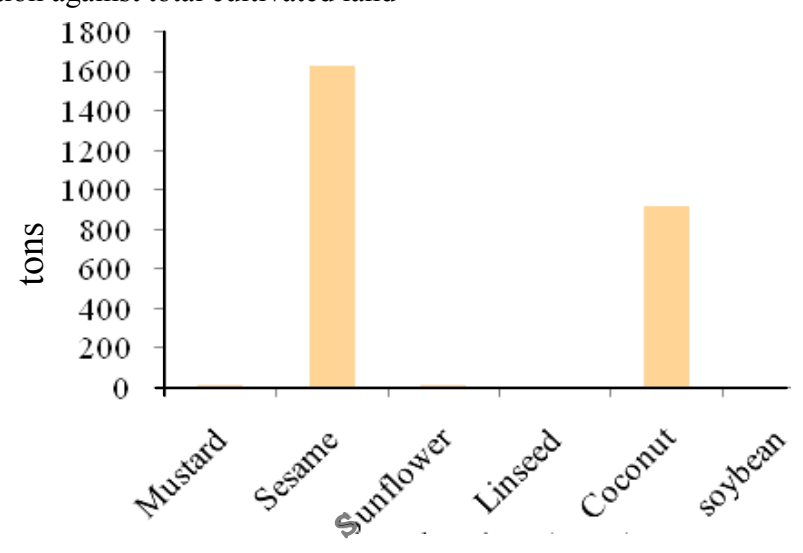

Production (tons)

Fig. 4. Oilseeds distribution on the basis of land utilization

There were 3,812 landless farmers in Batiaghata upazila. The number of marginal farmer was 8,103 among which 2,403 farmers were oilseed growers; 15,481 farmers were in small farmer category among which 9,288 farmers were oilseed growers; 5,275 farmers were in medium farmer category where 2,110 were oilseed growers and 884 farmers were in large category where 780 were oilseed growers (Fig. 5).

The number of agricultural training and oilseed training was not so much (Table 1). There were many agricultural training but the number of oilseed training

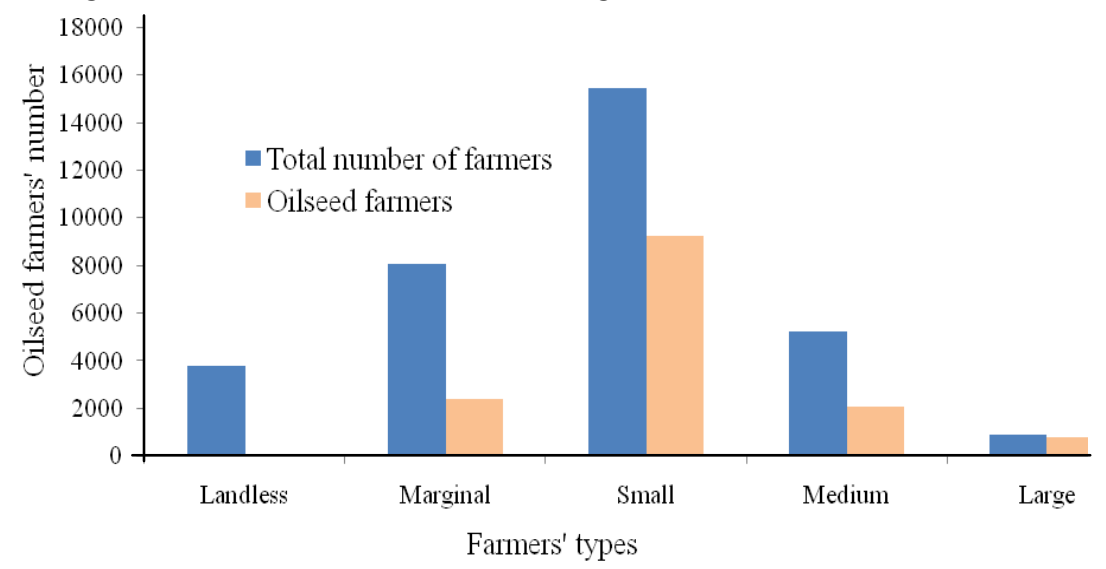

Fig. 5. Categorical distribution of oilseed farmers on the basis of land ownership

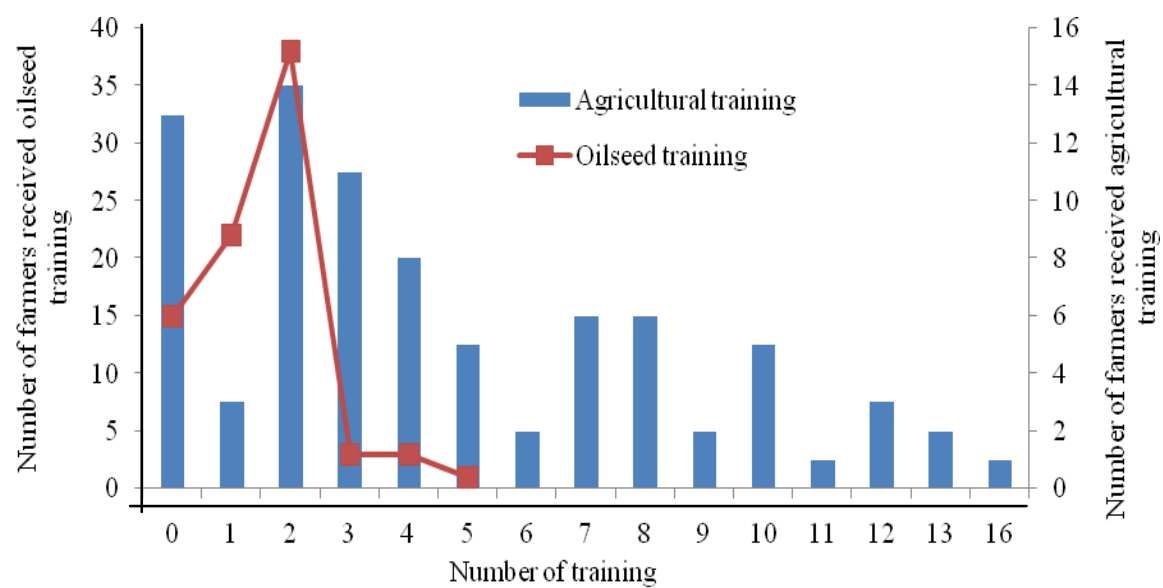

203 was very low in comparison with agricultural training (Fig. 6). It is observed in Fig. 6 that 13 respondents didn't receive any agricultural training and 15 didn't receive any oilseed training. Maximum number of agricultural training received was 16 by one respondent. Maximum frequency of training received was 2 (modal value). Among the respondents 38 respondents received 2 oilseed trainings and 14 respondents received 2 agricultural trainings. Maximum number of received oilseed training was 5 by one respondent. 
Fig. 6. Comparison between number of agricultural training and oilseed training

The maximum oilseed growers were small farmers. The marginal farmers cultivated less oilseeds as they cultivated rice for their family. Most of the large farmers cultivated oilseed as they had enough land for cultivating both rice and oilseed and they could invest more and take risk. The total oil requirement at Batiaghata upazila was 2,012 tons (approx.) per year whereas 1,620 tons (approx.) oilseed was produced here from which 324 tons (approx.) oil could be obtained (conversion $\sim 20 \%$ oil concentration on an average). Maximum produced amount was sesame which was not locally consumed. So the required oils for consumption needed to be bought by the farmers. If the farmers start to cultivate sunflower or mustard or soybean then they can fulfill their daily requirement from their farm produce. There was an oilseed project (govt. financed) running in the upazila namely "improved pulse, oilseed, and onion production, storage and distribution project at farmer level". There were 10 demonstration plots of sesame, 4 demonstration plots of mustard at the upazila. Some NGOs like BRAC had some activity in this area regarding oilseed cultivation. They distributed some demonstration plots of sunflower among the farmers. There was no regular training activity at upazila level regarding oilseed cultivation and oil processing.

\section{Knowledge, attitude and practice:}

\section{(i) Knowledge on oilseed cultivation}

The knowledge score ranged from 5 to 10 against the possible range from 0 to 10 . Table 2 represents the distribution of the farmers according to the knowledge on oilseed cultivation.
Data (Table 2) reveal that about two third (68.3 percent) of the respondents had high knowledge regarding oilseed cultivation compared to 31.7 percent had medium knowledge. As the respondents cultivated oilseed for long time they had knowledge about it. However, sesame was the highest cultivated oilseed crop in the study area and the knowledge was confined mainly in sesame cultivation.

\section{(ii) Attitude towards oilseed cultivation}

The observed attitude scores towards oilseed cultivation of the farmers ranged from 30 to 48 having the average of 36.95 against the possible range of 10 to 50 (Table 3 ).

The findings show that most of the farmers (81.7 percent) had favorable attitude towards oilseed cultivation compared to (17.1 percent) having highly favorable attitude. It could be said that the farmers of the study area had positive attitude for oilseed cultivation.

\section{(iii) Practice regarding oilseed cultivation}

\section{Last five years cropping pattern}

Last five years cropping pattern has been presented in Table 4. Cropping pattern of the survey area was computed on the basis of crops cultivated in 3 cropping seasons namely Kharif-I, Kharif-II and Rabi. Ladies finger ranked first position (citation score 143), sweet gourd second position (citation score 127) and yard long bean third position (citation score 110) among other vegetables cultivated in Kharif-I season. In Kharif-II season most of the fields remain occupied by T-Aman. In Rabi season oilseeds (such as sesame and sunflower) and mungbean were cultivated. Sesame was the mostly cultivated oilseed during Rabi season (Table 4).

Table 2. Distribution of the respondents according to knowledge on oilseed cultivation

\begin{tabular}{|c|c|c|c|c|c|c|c|c|}
\hline \multirow{2}{*}{$\begin{array}{l}\text { Parameter } \\
\text { / Variable }\end{array}$} & \multirow{2}{*}{ Category } & \multirow{2}{*}{ Score } & \multicolumn{2}{|c|}{ Respondents ( $\mathrm{N}=82)$} & \multirow{2}{*}{ Mean } & \multirow{2}{*}{ SD } & \multirow{2}{*}{ Min. } & \multirow{2}{*}{ Max. } \\
\hline & & & Number & Percentage & & & & \\
\hline \multirow{3}{*}{$\begin{array}{c}\text { Knowledge } \\
\text { (Score) }\end{array}$} & Low & $1-3$ & 0 & 0 & \multirow{3}{*}{8.02} & \multirow{3}{*}{1.47} & \multirow{3}{*}{5} & \multirow{3}{*}{10} \\
\hline & Medium & $4-7$ & 26 & 31.7 & & & & \\
\hline & High & $>7$ & 56 & 68.3 & & & & \\
\hline
\end{tabular}

Table 3. Distribution of respondents according to their attitude towards oilseed cultivation

\begin{tabular}{|c|c|c|c|c|c|c|c|c|}
\hline \multirow{2}{*}{$\begin{array}{l}\text { Parameter } \\
\text { / Variable }\end{array}$} & \multirow{2}{*}{ Category } & \multirow{2}{*}{ Score } & \multicolumn{2}{|c|}{ Respondents $(\mathrm{N}=82)$} & \multirow{2}{*}{ Mean } & \multirow{2}{*}{ SD } & \multirow{2}{*}{ Min. } & \multirow{2}{*}{ Max. } \\
\hline & & & Number & Percentage & & & & \\
\hline \multirow{4}{*}{$\begin{array}{l}\text { Attitude } \\
\text { (Score) }\end{array}$} & Less favorable & $10-20$ & 0 & 0 & \multirow{4}{*}{36.95} & \multirow{4}{*}{5.07} & \multirow{4}{*}{30} & \multirow{4}{*}{48} \\
\hline & $\begin{array}{c}\text { Moderately } \\
\text { Favorable }\end{array}$ & $21-30$ & 1 & 1.2 & & & & \\
\hline & Favorable & $31-40$ & 67 & 81.7 & & & & \\
\hline & $\begin{array}{c}\text { Highly } \\
\text { favorable }\end{array}$ & $41-50$ & 14 & 17.1 & & & & \\
\hline
\end{tabular}


Table 4. Last five years cropping pattern

\begin{tabular}{|c|c|c|c|c|c|c|c|c|c|}
\hline \multirow{2}{*}{ Season } & \multirow{2}{*}{ Serial } & \multirow{2}{*}{ Crops } & \multicolumn{7}{|c|}{ Citation frequency } \\
\hline & & & 2012 & 2013 & 2014 & 2015 & 2016 & Total & Rank \\
\hline \multirow{14}{*}{ 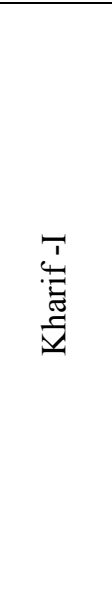 } & 01. & Ladies finger & 27 & 30 & 25 & 31 & 30 & 143 & $1^{\mathrm{st}}$ \\
\hline & 02. & Sweet gourd & 26 & 24 & 28 & 23 & 26 & 127 & $2^{\text {nd }}$ \\
\hline & 03. & Yard long bean & 18 & 18 & 28 & 24 & 22 & 110 & $3^{\text {rd }}$ \\
\hline & 04. & Red amaranths & 17 & 28 & 27 & 18 & 13 & 103 & $4^{\text {th }}$ \\
\hline & 05. & Bitter gourd & 15 & 20 & 23 & 19 & 22 & 99 & $5^{\text {th }}$ \\
\hline & 06. & Ridge gourd & 16 & 20 & 16 & 19 & 16 & 87 & $6^{\text {th }}$ \\
\hline & 07. & Brinjal & 11 & 17 & 9 & 10 & 15 & 62 & $7^{\text {th }}$ \\
\hline & 08. & Chili & 9 & 12 & 10 & 9 & 13 & 53 & $8^{\text {th }}$ \\
\hline & 09. & Watermelon & 6 & 4 & 8 & 15 & 19 & 52 & $9^{\text {th }}$ \\
\hline & 10. & Tomato & 13 & 9 & 10 & 8 & 6 & 46 & $10^{\text {th }}$ \\
\hline & 11. & Bean & 10 & 8 & 6 & 10 & 7 & 41 & $11^{\text {th }}$ \\
\hline & 12. & Bottle gourd & 6 & 8 & 8 & 7 & 11 & 40 & $12^{\text {th }}$ \\
\hline & 13. & Cauliflower & 1 & 3 & 4 & 6 & 3 & 17 & $13^{\text {th }}$ \\
\hline & 14. & Cabbage & 2 & 2 & 5 & 5 & 2 & 16 & $14^{\text {th }}$ \\
\hline 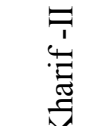 & 15. & T-Aman & 75 & 77 & 77 & 71 & 72 & 372 & \\
\hline \multirow{3}{*}{$\begin{array}{l}\overrightarrow{0} \\
\tilde{\pi}\end{array}$} & 16. & Sesame & 65 & 64 & 62 & 58 & 65 & 314 & $1^{\text {st }}$ \\
\hline & 17. & Mungbean & 21 & 24 & 18 & 28 & 26 & 117 & $2^{\text {nd }}$ \\
\hline & 18. & Sunflower & - & - & 15 & 21 & - & 41 & $3^{\text {rd }}$ \\
\hline
\end{tabular}

Cultivated major oilseed crops in the locality: Sesame and sunflower were the cultivated major oilseed crops (Table 5).

Table 5. Cultivated major oilseed crops in the locality

\begin{tabular}{cc}
\hline Crops & Citation frequency \\
\hline Sesame & 82 \\
Sunflower & 79 \\
\hline
\end{tabular}

Purpose of oilseed cultivation: The main purpose of oilseed cultivation was income generation (Table 6).

Table 6. Purpose of oilseed cultivation

\begin{tabular}{cc}
\hline Purpose & Citation frequency \\
\hline Income generation & 82 \\
Fulfillment of family need & 17 \\
\hline
\end{tabular}

Problem confrontation in oilseed cultivation:

Problem confrontation score about oilseed cultivation by the farmers was computed on the basis of problem faced in case of oilseed cultivation. Their score ranged from 8 to 35 against the possible range of 0 to 60 . Their average score was 16.63 and, standard deviation was 5.34. Majority (58.5 percent) of the farmers confronted medium problem regarding oilseed cultivation compared to 39 percent of the respondents confronted less problem on oilseed cultivation. Only 2.4 percent farmers had severe problem confrontation in oilseed cultivation (Table 7).

Table 7. Distribution of respondents according to the problems confronted in oilseed cultivation

\begin{tabular}{|c|c|c|c|c|c|c|c|c|}
\hline \multirow{2}{*}{$\begin{array}{c}\text { Parameter/Vari } \\
\text { able }\end{array}$} & \multirow{2}{*}{ Category } & \multirow{2}{*}{ Score } & \multicolumn{2}{|c|}{ Respondents $(\mathrm{N}=82)$} & \multirow{2}{*}{ Mean } & \multirow{2}{*}{ SD } & \multirow{2}{*}{ Min. } & \multirow{2}{*}{ Max. } \\
\hline & & & Number & Percentage & & & & \\
\hline \multirow{4}{*}{$\begin{array}{l}\text { Problem } \\
\text { (Score) }\end{array}$} & Less & $\geq 15$ & 32 & 39 & \multirow{4}{*}{16.63} & \multirow{4}{*}{5.34} & \multirow{4}{*}{8} & \multirow{4}{*}{35} \\
\hline & Medium & $16-30$ & 48 & 58.5 & & & & \\
\hline & Severe & $31-45$ & 2 & 2.4 & & & & \\
\hline & Highly severe & $46-60$ & 0 & 0 & & & & \\
\hline
\end{tabular}

Water logging was the first ranked problem in oilseed cultivation (Table 8). Due to heavy rainfall and inadequate drainage system water logging caused great harm to oilseed crop cultivated in the area. Salinity was the second ranked problem in oilseed cultivation. Due to 
salinity and low land elevation other oilseed crops such as mustard cannot be cultivated here.

Table 8. Severity index and rank order of the confronted problems in oilseed cultivation

\begin{tabular}{|c|c|c|c|c|c|c|c|c|}
\hline \multirow[b]{2}{*}{ Serial } & \multirow[b]{2}{*}{ Problems } & \multicolumn{5}{|c|}{ Severity of problem } & \multirow[b]{2}{*}{ Total } & \multirow[b]{2}{*}{ Rank } \\
\hline & & $\begin{array}{c}\text { No problem } \\
(0)\end{array}$ & $\begin{array}{c}\text { Less } \\
\text { severe }(1)\end{array}$ & $\begin{array}{c}\text { Medium } \\
\text { severe (2) }\end{array}$ & $\begin{array}{l}\text { Severe } \\
\text { (3) }\end{array}$ & $\begin{array}{c}\text { Highly } \\
\text { severe (4) }\end{array}$ & & \\
\hline a. & $\begin{array}{l}\text { Lack of suitable land for } \\
\text { oilseed cultivation }\end{array}$ & 13 & 32 & 19 & 18 & - & 115 & $5^{\text {th }}$ \\
\hline b. & Lack of quality seed & 26 & 34 & 15 & 3 & 4 & 89 & $7^{\text {th }}$ \\
\hline c. & $\begin{array}{l}\text { Lack of sufficient quantity of } \\
\text { fertilizer }\end{array}$ & 37 & 29 & 8 & 3 & 1 & 58 & $9^{\text {th }}$ \\
\hline d. & Lack of storage facility & 11 & 34 & 31 & 4 & 2 & 116 & $4^{\text {th }}$ \\
\hline e. & $\begin{array}{l}\text { Lack of training, skill and } \\
\text { experience }\end{array}$ & 16 & 42 & 16 & 6 & 2 & 100 & $6^{\text {th }}$ \\
\hline f. & $\begin{array}{l}\text { Lack of improved technology } \\
\text { for planting and harvesting }\end{array}$ & 8 & 28 & 27 & 17 & 2 & 141 & $3^{\text {rd }}$ \\
\hline g. & $\begin{array}{l}\text { Insect- pest and disease } \\
\text { infestation }\end{array}$ & 11 & 36 & 27 & 7 & 1 & 115 & $5^{\text {th }}$ \\
\hline h. & Lack of marketing facilities & 42 & 29 & 9 & 2 & - & 53 & $10^{\text {th }}$ \\
\hline i. & Transportation problem & 73 & 9 & - & - & - & 9 & $13^{\text {th }}$ \\
\hline $\mathrm{j}$. & Lack of internal motivation & 43 & 39 & - & - & - & 39 & $11^{\text {th }}$ \\
\hline $\mathrm{k}$. & Unavailability of information & 48 & 30 & 4 & - & - & 38 & $12^{\text {th }}$ \\
\hline 1. & Drought & 39 & 27 & 14 & 2 & - & 61 & $8^{\text {th }}$ \\
\hline $\mathrm{m}$. & Water logging & 3 & 10 & 29 & 32 & 8 & 196 & $1^{\text {st }}$ \\
\hline n. & Salinity & 10 & 24 & 12 & 24 & 12 & 168 & $2^{\text {nd }}$ \\
\hline o. & Not habituated & 28 & 42 & 8 & - & - & 58 & $9^{\text {th }}$ \\
\hline
\end{tabular}

Relationship between the selected characteristics of oilseed farmers and problem confrontation:

Coefficient of correlation was computed in order to explore the relationship between the selected characteristics of oilseed farmers and problem confrontation. Pearson's Product Moment coefficient (r) was used.

It was observed in Table 9 that annual income of the farmers had significant negative relationship with their lower the degree of problem confrontation. Higher income group farmers normally receive more training and facilities, and they have higher cosmopoliteness. So, they can discuss more about the problems and can have preventive measures against the problems. Attitude towards oilseed cultivation of the farmers had highly significant negative relationship with their degree of problem confrontation in oilseed cultivation. Those farmers who face fewer problems, had positive attitude. degree of problem confrontation in oilseed cultivation. It means that the higher the income of respondents the

Table 9. Relationship between the selected characteristics of oilseed farmers and problem confrontation

\begin{tabular}{lcc}
\hline \multicolumn{1}{c}{ Characteristics (independent variable) } & Dependent variable & Correlation co-efficient \\
\hline Age & & -0.055 \\
Education & & -0.087 \\
Family members & & 0.128 \\
Farm size & Problem confrontation in & -0.040 \\
Werea under oilseed & oilseed cultivation & 0.050 \\
Organizational participation & & -0.160 \\
Annual income & & $-0.316^{* *}$ \\
Extension contact & & 0.098 \\
Cosmopoliteness & -0.095 \\
Agricultural training number & -0.177 \\
Training on oilseed number & & -0.206
\end{tabular}




\section{**, Correlation was significant at the 0.01 level}

\section{Conclusion}

Most of the respondents were middle to old aged, having secondary to higher secondary education, small farm size, low organizational participation, low annual family income, medium extension contact, low to medium cosmopoliteness and maintained nuclear family. They had experience of oilseed cultivation and received training on oilseed cultivation. Number of agricultural training and oilseed training was not much. Total number of oilseed training was very less comparing with total agricultural training. Rice was most widely cultivated crop and thus occupied more arable land comparing with other crops like oilseed, horticultural crops, jute and other crops. The total area occupied by oilseed was very low comparing with all crops occupied area and thus production of oilseed was also very meager. Among oilseeds sesame occupies most of the area and production was fairly high. Most of the farmers were in small farm size category on the basis of land ownership. The total oil production cannot satisfy the local demand of oil. Furthermore sesame was mostly produced oilseed on the area and they don't consume sesame oil. The respondents had medium to high knowledge on oilseed cultivation with favorable to highly favorable attitude. Ladies finger was first ranked crop in Kharif -I season, T-Aman in Kharif-II season, and sesame in Rabi season in respect of cultivation coverage. The main purpose of oilseed cultivation was income generation. Respondents faced less to medium problem in oilseed cultivation. Water logging was first ranked problem faced by the respondents. Among various selected characteristics of the respondents' attitude and annual income showed negative significant relationship with problem confrontation.

On the basis of the above findings it might be concluded that the farmers of the study area had favorable attitude towards oilseed cultivation. This attitude may be a tool for the oilseed farmers to increase the oilseed production. Appropriate extension strategy related to oilseed cultivation should be developed to increase the oilseed production in that area.

\section{References}

Akanda, M., Badhan, A. and Haque, A.T.M.S. 2017. Farmer's level motivation on sunflower cultivation in a rice based cropping pattern of Patuakhali district, Asian Journal of Agricultural Extension, Economics \& Sociology, 18(2): $1-11$.

BARI. 2008. Adoption and Relative Profitability of Mustard Production in Bangladesh, Annual Research Report 200708, Oilseed Research Centre, BARI, Joydebpur, Gazipur.

Bashar, M.A. 2006. Problem confrontation of the farmers in mushroom cultivation, MS Thesis in Agricultural Extension and Information System, Sher-e-Bangla Agricultural University, Dhaka.

Hossain, T. 2017. Bangladesh Oilseeds and Products Annual, Global Agricultural Information Network, USDA Foreign Agriculture Service (GAIN Report No. BG7002), pp. 2-5.

http://en.banglapedia.org, Retrieved on November 30, 2017 (http://en.banglapedia.org/index.php?title=Oil Plant)

Likert R, 1932. A Technique for the Measurement of Attitudes, Archives of Psychology, 140: 1-55.

McKevith, B. 2005. Nutritional aspects of oilseeds, Nutrition Bulletin, 30(1): 13-26.

Rizvi, R., Mahmood, I., Tiyagi, S.A. and Khan, Z. 2012. Conjoint effect of oilseed cakes and Pseudomonas fluorescens on the growth of chickpea in relation to the management of plant parasitic nematodes, Brazilian Archives of Biology and Technology, 55(6): 801-808.

Tongco, M.D.C. 2007. Purposive sampling as a tool for informant selection, Ethnobotany Research \& Applications, 5: $147-158$.

www.dailynayadiganta.com, Retrieved on November 15, 2017 (http://old.dailynayadiganta.com/detail/news/268480).

Yanai, H., Katsuyama, H., Hamasaki, H., Abe, S., Tada, N. and Sako, A. 2015. Effects of dietary fat intake on HDL metabolism, Journal of Clinical Medicine Research, 7(3): 145-149. 